\title{
Elements of Language and Assimilation of Malay Language in Baba and Nyonya Community in Malaysia
}

\author{
Dr. Vijayaletchumy Subramaniam \\ Department of Malay Language, Faculty of Modern Languages and Communication \\ Universiti Putra Malaysia \\ Serdang, Selangor, Malaysia \\ E-mail: letchumy@fbmk.upm.edu.my \\ Wan Muna Ruzanna Wan Mohammad \\ Department of Malay Language, Faculty of Modern Languages and Communication \\ Universiti Putra Malaysia \\ Serdang, Selangor, Malaysia \\ E-mail: munaruzanna@yahoo.com
}

\begin{abstract}
The purpose of this research is to identify the elements of language and to study the strength of the assimilation of the Malay language used by the Baba and Nyonya in Malacca. This research is focusing on the aspects of language that cover the usage level of the language, pronunciation, spelling, vocabulary and others. This research uses library research, survey, observation and interview. Questionnaires have been distributed to all respondents as the procedure to conduct the research. The level of the assimilation of the Malay language in Baba and Nyonya has been analyzed from the angles of frequency, mean and standard deviation and are explained rationally.
\end{abstract}

Keywords: Elements of language, Assimilation, Baba ang Nyonya Community

\section{Background}

One of the clusters that used Malay language in the peninsular Malacca was Chinese, and they used it from generation to generation since they lived there long time ago. They did not use the Chinese language at that time. In fact some of them even married to the locals and they termed themselves as Baba and Nyonya. The language of this Baba and Nyonya in Singapore, Malacca and Penang was known as the varieties of Baba Malay language. The language of Baba and Nyonya is the mixture of the Malay language and the Hokkien dialect. Most of the grammar aspects in Baba and Nyonya language came from the Malay language. However, this Baba language is different from the Malay language in so many aspects. That is the reason why it is different from the Malay language. The Baba Malay language has absorbed many Chinese words, such as 'lai' (Hokkien dialect) for the word 'come' and many other examples that Malay community does not understand until the $19^{\text {th }}$ century, when Baba started to develop its stable and unique community. The use of Malay language is one of the unique aspects that this community has. From the mixture of the languages, one language was born which later they called it Baba language and they used it as the mother tongue of the community (Shellabear, 1913).

\section{Objective of the Study}

To identify the elements of language and the strength of the assimilation of the Malay language in the Baba and Nyonya daily lifestyles in Malacca.

\section{Importance of the Study}

This research is important to the new generations of Baba and Nyonya so that they will not regard the Baba language as a dead language. 


\section{Past Research}

Louis Wirth (1945), assumed that the Chinese community who lived at the river bank of Sungai Kelantan as the assimilation cluster because they were not only using Bahasa Melayu as the daily communication tool, but the way they dressed up was very similar to the Malay people and most of their aspect of lives were also similar to the local Malays. They even called themselves as 'Chinese-Malay people'.

\section{METHODOLOGY}

\section{Research Limitations}

This research is limited to people from the Baba and Nyonya community who have been used as the respondents of this research. This research also focuses on the elements of language and the strength of the assimilation of the Malay language in the Baba and Nyonya daily lifestyles in Malacca

\section{Research Design}

i. Library research: This method is used because there so many magazines, journals and thesis and books that have been used as references to hold the arguments strongly.

ii. Interview: Researcher has interviewed respondents to gather clear and accurate information.

iii. Observation: Researcher also has done an observation towards the lifestyle patterns of the Baba and Nyonya community.

\section{Research Instruments}

i. Questionnaire: The questionnaires have been distributed to the respondents to answer all the questions asked to them.

ii. Tape recorder: Is used to record the interaction and daily lifestyle pattern of the Baba and Nyonya community.

\section{Data Analysis}

i. SPSS: The raw data obtained are transferred to the SPSS programme. The data was analysed by using the format based on the research category conducted. The data obtained was analysed quantitatively to get the frequency, mean and standard deviation.

\section{Research Findings}

Objective: To identify the elements of language and the strength of the assimilation of the Malay language in the Baba and Nyonya daily lifestyles in Malacca.

\section{Language Use at Home}

Based on the questionnaires, observation and survey done while conducting the research, the following findings are obtained:

\section{Insert Graph 1 here}

Parallel with the objective above, researcher would like to see the outcome from the prospective of language assimilation; combination of Chinese and Malay which later on gave birth to this Baba Malay language.

Graph 1 above shows the language used by the Baba and Nyonya in their daily lifestyles. Most of the Baba and Nyonya are still using the Malay language in their daily conversation.

The Malay language is still playing its important role in their lives when $48 \%$ of the Baba and Nyonya still use Malay language. Although, the usage of Malay language does not reach $50 \%$ yet, we can still be proud of it. This happens because the Baba and Nyonya love what their great ancestors had left them with.

To the earliest generation who are still alive and well, they feel fresher in using the Baba Malay language as their mother tongue when communicating with the locals and their family members. As for the family members who come from the new generation, they have to learn the language in order for them to communicate with the old ones. Since they are still maintaining their settlement and spending their life in that particular area, their Malay language is getting better and better. This is so very different from today's generations.

From the other aspect, language mixture such as the use of Malay language and Chinese, and 'rojak language' (the use of both languages alternately) is widely used. The percentage of using Chinese and Malay language is $38 \%$. The mixture of these languages is due to the factor of sending their children to Chinese schools. This happens when the parents are actually Baba and Chinese and they are inclined to follow the Chinese culture more than the Baba's. As a result, the children learn Mandarin and it becomes their mother tongue. 


\section{Insert Table 1 here}

Table 1 shows the usage of language for the daily conversation of the Baba and Nyonya. There are altogether 65 Baba and Nyonya used as the respondents. From that number, $47.7 \%=31$ respondents still use Malay language as their medium of interaction at home. $38.5 \%=25$ respondents use the mixture of Malay and Chinese (Baba language). Only $13.8 \%=9$ respondents use other languages. These respondents use English language as their medium of communication. This matter shows that Malay language is still obvious to be used by the Baba and Nyonya. Based on the interview done, it is found that if in the family, they have old people, automatically they will be using the Malay and the Baba language. The mean for the language used is 2.18 and the standard deviation is 1.184 .

\section{The Level of Mastering the Malay Language}

Insert Graph 2 here

\section{Insert Table 2 here}

Graph 2 and Table 2 above show the mastery level of Malay among the Baba and Nyonya. From the aspect of communicating, there are 57 respondents $=87.7 \%$ can speak fluently. From the aspect of reading, $47=72.3 \%$ of the respondents can read properly. And last but not least, from the aspect of writing, $46=70.8 \%$ respondents can write.

This case shows that, all respondents have the basic knowledge of the vocabulary of the Malay language because the respondents know how to speak the language. The respondents can also read and write well. This is because the alphabetical letters of English language are similar to the Malay language and other languages in the world. However, the Chinese language has different alphabetical letters from the Malay language and it is known as calligraphy.

The new generation is very fluent in communicating, reading and writing in the Malay language because they receive their education from the Malay medium schools (both primary and secondary schools). They are also exposed to the mixture of languages if happens that the Baba and Chinese married together. This matter will somehow affect the usage of their Malay language, but will upgrade their mastery of the Chinese and English language.

Table 2 shows the mean distribution and standard deviation depending on the dimension that measures the level of mastery of the Malay language to the Baba and Nyonya community. It is found out that the highest mean for the writing dimension is 2.00 and the standard deviation is 0.612 . This means that, the writing dimension is the most influenced dimension compared to speaking and reading. In the Baba language, there is a short form system to shorten words in Malay by dropping the syllables of the word. Among the words are:

\section{Insert Table 3 here}

Table 3 shows the situation of shorten down certain words that exist in the Baba language. On the other hand, there are also cases like, errors in pronunciation. For instance, 'ambil' - take (BM) becomes 'ambek' (BB), 'kerusi' - chair (BM) becomes 'krosi' (BB), and these errors are more obvious to the word 'pengantin' - bride (BM) becomes 'kēmantēn' (BB).

\section{Insert Table 4 here}

Table 4 displays the changes made in the Malay language done by the Baba and Nyonya community. The word 'tingkap'- window (BM) has been changed to 'menyelah' (BB). In Malay, there is also word that has similar meaning with 'menyelah' (BB), and the word is 'selak = menyelak' (browse / peep) (BM) which means looking at the other side. The word 'rezeki'-good fortune (BM, BA) has been changed to 'jerki' (BB), the changes to these words are not made up, but the Baba and Nyonya is naturally cannot pronounce the letter ' $r$ ' correctly. This is similar to the word 'sumpit' (BB), the Chinese do not have the syllable 'se' in the Chinese language, so the replacement is made by the syllable 'sum'.

\section{Insert Table 5 here}

Table 5, shows some borrowed words from Java and Indonesia. This situation happens due to the interaction that the Baba had with the Javanese from the Java Island who came to Tanah Melayu last time.

\section{Insert Table 6 here}

Table 6 shows words that are borrowed directly from the Malay language and 'market language'. From the Baba word 'kasi', 'bini', 'bikin', 'jantan', and 'betina' are considered as the 'market language' to the Malay language. Those words are uttered in certain places only; market, during informal communication with friends and in one's 
hometown. This is because the words are rough and negative and only at those places mentioned above the words are suitable to be used in the conversation.

\section{Insert Table 7 here}

Table 7 shows the combination of Malay and Chinese language (Hokkien). The word 'ayam tim' (BB) which means 'ayam kukus'- Steamed Chicken (BM). This word is the combination of the word 'ayam'-chicken (BM) and 'tim' (BC - Hokkien) that means 'steam' in Malay. This is similar to the word 'batu boh' (BB) which means 'batu giling'-hard bowl (BM). The word 'batu'- hard/stone comes from Malay, and the word 'boh' is a Chinese word 'boa' in BC- Hokkien means to pound or blend. To the word 'makan tēpo' (BB) which is referring to the ceremony of eating one type of Chinese noodles together with drinking the Chinese tea exactly after the bride arrives at the groom's house according to the wedding ceremony of Baba and Nyonya. The word 'makan' - eat (BM), and the word 'tēpo' (BC- Hokkien) refers to serving of tea. Both words are combined to form the exact meaning according to their understanding. The language of Baba and Nyonya is the combination languages of Malay and Chinese (Hokkien) whereas the grammar of Baba language comes from the Malay language.

\section{Frequency of Using Malay language in the Family \\ Insert Graph 3 here \\ Insert Table 8 here}

Table 8 shows the differences between two questions, 15 and 16. These questions are to show the frequency of using the Malay language and Baba language. The use of Malay dialect shows 52 respondents $=80 \%$ use Malay regularly (always) in their conversation. This is different from the usage of Baba dialect where $43=66.2 \%$ of the respondents are still using the Baba dialect in their daily conversation. Since the respondents are Baba and Nyonya, definitely they have more than one languages to be used while communicating. Only one respondent $(1.5 \%)$ rarely used the Malay dialect. Surprisingly, there are these people in the Baba and Nyonya community who do not use the Baba language in their conversation. This situation is captured in these 12 respondents = $18.5 \%$ who do not choose to use the Baba language to communicate.

Table 8 also shows the distribution of mean and standard deviation depending on the dimension in measuring the frequency of the usage of Malay language to the Baba and Nyonya. It is found out that, the highest mean is to the dimension of the Malay language, 1.74 and the standard deviation is 0.523 . This means that, the dimension of the frequency in the usage of the Malay language is the most communicated one compared to the Baba language.

\section{Language Used During Communication}

\section{Insert Table 9 here}

Table 9 portrays the usage of language in communication with family, neighbour, community and people in the office. From the aspect of family, the Baba language is still widely used, where $27=41.5 \%$ respondents said so. This situation happens when there is an old generation in the family ( $3^{\text {rd }}$ and $4^{\text {th }}$ generations). The old generation of Baba and Nyonya cannot speak Chinese and any other languages. Due to that the new generation has to learn the Baba language in order to speak with them.

From the aspect of neighbourhood, the language use is Malay where $41=63.1 \%$ respondents used Malay language. Most of these Baba and Nyonya settlements are very near to the Malays and that is why they speak Malay compared to other languages. Not only the language, but their way of life is also similar to the Malays.

From the aspect of community, we could also see a high percentage when 60 respondents $=93 \%$ use Malay language when communicating. This is due to Malay language is the formal and official language of the country. Malay language is also used as the medium of instruction in many schools. Therefore, the Baba and Nyonya feel more comfortable in using Malay language in their communication with other races; Indian, Chines and even Malay themselves.

From the aspect of administrative (in the office), $61=93.8 \%$ of the respondents use Malay language as their medium of instruction as well. All the administrative work is dealt in Malay. Letters are written in Malay too for the convenience of everyone.

Table 9 also displays the mean distribution and the standard deviation depending on the dimension to measure the usage of the Malay and Baba language. It is found out that, the highest mean is on the neighbourhood dimension, with 2.48 and the standard deviation is 0.687 . This matter means that the neighbourhood dimension has its own strength in using Malay language in their communication. 


\section{Conclusion}

Now, the Baba and Nyonya community is still using their Baba language daily. Both these Baba and Malay languages act as their main conversation languages especially to the $3^{\text {rd }}$ and $4^{\text {th }}$ generations (the old generations). They use the Malay language when communicating with their neighbours, family members and people around them, including those at their workplace. The usage level of this language depends on the existence of these $3^{\text {rd }}$ and $4^{\text {th }}$ generations in their family.

\section{References}

Alex Inkeles. (1985). Terjemahan Cheu Hock Tong, Apa Itu Sosiologi?. Kuala Lumpur: Dewan Bahasa dan Pustaka.

Asmad. (1990). Perayaan Orang Cina. Kuala Lumpur: Penerbitan Fajar Sdn. Bhd.

Enloe, C.H. (1970). Multi-Ethnic Politics: The Case of Malaysia. Research Monograph Sries, University of California.

http://ms.wikipedia.org/wiki/baba

http://ms.wikipedia.org/wiki/Melaka

Rahim Syam dan Norhale. (1985). Mendekati Kebudayaan Melayu. Petaling Jaya, Selangor: Penerbitan Fajar Sdn. Bhd.

Seminar Kefahaman Budaya. (December 1999). Kementerian Kebudayaan, Kesenian dan Pelancongan Malaysia. Kuala Lumpur: Terbitan Cawangan Pemuliharaan Kebudayaan Kementerian Kebudayaan, Kesenian dan Pelancongan.

Tan Chee Beng. (1993). Chinese Peranakan Herittage In Malaysia and Singapore. Selangor: Penerbitan Fajar Sdn. Bhd.

Wan Abdul Kadir. (1993). Perubahan Budaya Melayu. Petaling Jaya, Selangor: Masfani Enterprise.

Table 1. The usage of Daily Language

\begin{tabular}{lll}
\hline & \multicolumn{2}{l}{ LANGUAGE OF CONVERSATION } \\
ITEM & MalayMalay and Chinese language (Baba)Others \\
N & 65 & \\
Frequency & $31 \quad 25$ & 9 \\
Percentage & $47.7 \% 38.5 \%$ & $13.8 \%$ \\
Mean & 2.18 & \\
Standard Deviation 1.184 & \\
\hline
\end{tabular}

Table 2. The Level of Mastering the Malay Language of the Baba dan Nyonya

\begin{tabular}{llll}
\hline \multicolumn{2}{c}{ LEVEL OF MASTERING THE MALAY LANGUAGE } \\
ITEM & Spoken & Reading & Writing \\
Excellent & $7(10.8 \%)$ & $10(15.4 \%)$ & $9(13.8 \%)$ \\
Good & $57(87.7 \%)$ & $47(72.3 \%)$ & $46(70.8 \%)$ \\
Average & $1(1.5 \%)$ & $6(9.25)$ & $8(12.3 \%)$ \\
Poor & $0(0 \%)$ & $2(3.1 \%)$ & $2(3.1 \%)$ \\
N & 65 & & \\
Mean & 1.77 & 1.91 & 2.00 \\
Standard Deviation 0.523 & 0.341 & 0.612
\end{tabular}


Table 3. Short Forms of Words

\begin{tabular}{ll|}
\hline Malay Language & Baba Language \\
Tetapi (But) & Tapi \\
Sahaja (Only) & Saja \\
Perlahan (Slow) & Pelan \\
Ambil (Take) & Ambek \\
Kerusi (Chair) & Krosi \\
Pasu (Vase) & Paso \\
Pengantin (Bride/groom)kēmantēn \\
\hline
\end{tabular}

Table 4. The Changes Made to the Malay Language

\begin{tabular}{|lll|}
\hline Malay Language & \multicolumn{2}{c|}{ Baba LanguageBorrowed Language } \\
Tingkap (Window) & Menyelah & Jendela (B. Portugis) \\
Rezeki (Good fortune)Jerki & Rezeki (B. Arab) \\
Sepit (Stick) & Sumpit & Chopsticks (B.Inggeris) \\
\hline
\end{tabular}

Table 5. Borrowed Words

\begin{tabular}{|lll|}
\hline \multicolumn{3}{ll}{ Malay LanguageBaba LanguageBorrowed Word } \\
Telinga (Ear) & Kuping & Kuping (B. Jawa) \\
Katak (Frog) & Kodok & Kodok (B. Jawa) \\
Senduk (Ladle) & Senduk bes€ & Senduk bes€ \\
& & \\
& (sudu, camca) & (B. Jawa) \\
Cawan (Cup) & Cangkir & Cangkir \\
& & (B. Indonesia) \\
& & Bibi ((B. Indonesia) \\
\hline
\end{tabular}

Table 6. Borrowed Words Directly From Malay

\begin{tabular}{|ll|}
\hline Malay Language & Baba Language \\
Beri (Give) & Kasi \\
Isteri (Wife) & Bini \\
Buat (Do) & Bikin \\
Lelaki (Man) & Jantan (manusia/haiwan) \\
\multicolumn{2}{l}{ Perempuan (Woman)Betina (manusia/haiwan) } \\
\hline
\end{tabular}


Table 7. The Combination of Malay and Chinese Language

\begin{tabular}{lll}
\hline \multicolumn{2}{l}{ Malay Language } & \multicolumn{2}{l|}{ Chinese LanguageBaba Language } \\
\multicolumn{2}{l}{ Ayam kukus (Steamed Chicken)Ayam + tim } & Ayam tim \\
Batu giling (Hard bowl) & Boh = boa & Batu boh \\
Makan mee (Eating Noodles) & Teh $=$ tēpo & Makan tēpo \\
\hline
\end{tabular}

Table 8. The Differences of the Usage of Dialects

\begin{tabular}{lll}
\hline & \multicolumn{2}{l}{ DIFFERENCES OF USAGE OF DIALECTS } \\
ITEM & Malay Dialect & Baba Dialect \\
Always & $52(80.0 \%)$ & $43(66.2 \%)$ \\
Sometimes & $12(18.5 \%)$ & $8(12.3 \%)$ \\
Rarely & $1(1.5 \%)$ & $2(3.15)$ \\
Never & $0(0 \%)$ & $12(18.5 \%)$ \\
N & 65 & 65 \\
Mean & 1.74 & 1.28 \\
Standard Deviation 0.523 & 1.176
\end{tabular}

Table 9. Language Used During Communication

\begin{tabular}{|c|c|c|c|c|}
\hline \multirow{3}{*}{$\begin{array}{l}\text { ITEM } \\
\text { Baba Language }\end{array}$} & \multicolumn{4}{|c|}{ COMMUNICATION LANGUAGE } \\
\hline & Family & \multicolumn{3}{|c|}{ NeighbourCommunityOffice } \\
\hline & \multicolumn{2}{|c|}{$27(41.5 \%) 0(0 \%)$} & $0(0 \%)$ & $0(0 \%)$ \\
\hline Malay Language & \multicolumn{3}{|c|}{$14(21.5 \%) 41(63.1 \%) 60(92.3 \%)$} & $61(93.8 \%)$ \\
\hline \multicolumn{4}{|c|}{ Baba Language and Malay Language16 (24.6\%)17 (26.2\%)2 (3.1\%) } & $3(4.6 \%)$ \\
\hline English Language & $8(12.3 \%)$ & $7(10.8 \%)$ & $3(4.6 \%)$ & $1(1.5 \%)$ \\
\hline Others & $0(0 \%)$ & $0(0 \%)$ & $0(0 \%)$ & $0(0 \%)$ \\
\hline $\mathbf{N}$ & 65 & 65 & 65 & 65 \\
\hline Mean & 2.08 & 2.48 & 2.12 & 2.14 \\
\hline Standard Deviation & 1.080 & 0.687 & 0.451 & 0.556 \\
\hline
\end{tabular}




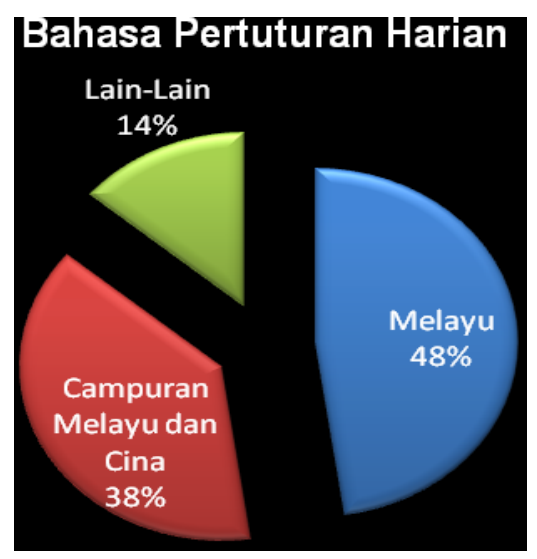

Graph 1. Daily language used by the Baba and Nyonya in Malacca

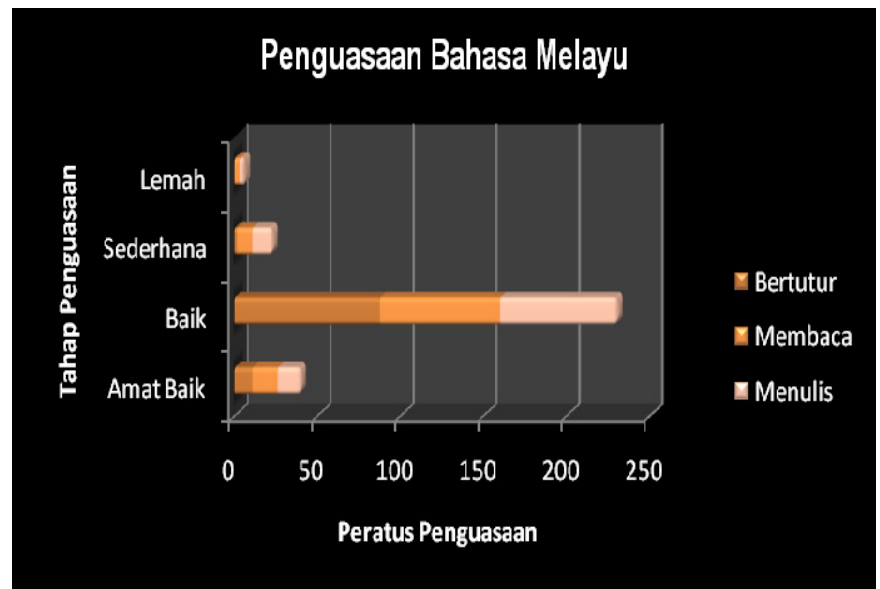

Graph 2. The level of mastering the Malay language among the Baba and Nyonya in Malacca

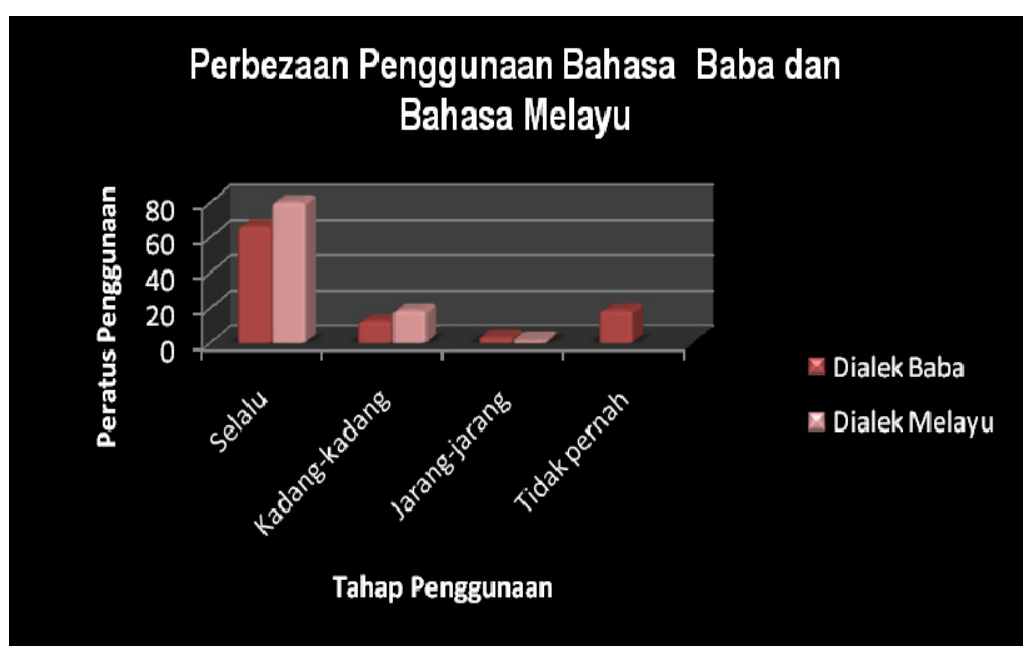

Graph 3. The Differences of Using Baba and Malay Language 